\title{
Promoting of Student's Cultural Understanding in General Education: Contradictions and Solutions
}

\author{
Ilze Briškaa ${ }^{1}$ Dr.paed., Mg.art.; Daiga Kalēja-Gasparoviča ${ }^{2}$ Dr.paed. \\ University of Latvia, Latvia \\ ilze.briska@lu.lv1,dkalga@lu.lv²
}

\begin{abstract}
The study is devoted to the clarification of the content and learning approach for the promoting students' cultural understanding in general school education. The aim of the study is to systematize the different curriculum designs and pedagogical approaches aimed at the development of learner's cultural understanding, and analyse their suitability for particular educational purposes. In the article, the concept cultural understanding is analysed theoretically, in the context of transmissive or transformative learning in order to help the all participants of general education (including teachers, politicians, teacher educators, researchers and school students) by clarifying the typical educational approaches and appropriate terminology for promoting the students' cultural understanding in general education. Empirical data come from interviews with educational experts and 72 surveys with pre- and in-service teachers. As a result of the study, the theoretical model of the promoting the cultural understanding in general education curriculum was constructed. The model will be useful for combining the content and approach of learning for promoting the student' $\mathrm{s}$ cultural understanding in accordance with particular educational goals in general school practice, teacher education and education policy.
\end{abstract}

Keywords: cultural understanding, content of learning, transformative learning, general education.

\section{Introduction}

Cultural understanding is a significant concept of ongoing education reform in Latvia. It is relatively new issue in Europe, too. The incorporation of the variety of cultural contexts in the general school curriculum is a challenge for school and pre-school teachers, teacher educators and policy makers. The problem is, that culture and understanding are very versatile concepts; there are no rational, quantitative, unambiguous criteria for its recognition and measurement. Depending on the focus, they can be interpreted as comprehensive or narrowly specific, relating to aesthetics or anthropology, superficial or profound. J. Fornäs argues, that different points of view have starkly contrasting implications and tend to create confusing contradictions if combined in the same discourse (Fornäs, 2017). It means, that educators cannot avoid these issues. What kind of promoting student's cultural understanding realized at school helps to achieve such educational goals as student's life-long learning competences, transversal skills, civic responsibility and sustainability in society, and which produces the opposite effect?

The aim of the study is to systematize the different curriculum designs and pedagogical approaches aimed at the development of learner's cultural understanding and analyse their suitability for particular educational purposes.

\section{Methodology}

To find the answer and to reach the aim, a qualitative study was conducted in four stages:

1. The theoretical analysis of the concept cultural understanding was proceeded in order to find out the varieties of its meaning;

2. The implementation of concept cultural understanding in education policy documents was analysed to highlight the most common approaches for including the culture in general school education.

3. The qualitative analysis of the general school teacher's experiences was done to find out the typical combinations of the content of learning and pedagogical approaches for promoting the students' cultural understanding in school practice.

4. A theoretical model of the promoting the cultural understanding in general education curriculum was constructed and completed with the appropriate terminology for the marking and describing a particular type of learning the culture. 
In the study, the information from three sources were compared - theoretical literature, European Union and Latvian educational policy documents and educational practitioners' experiences in Latvian schools.

In order to cover the broadest possible range of views on how cultural understanding is perceived by educators, the empirical data were obtained in interviews with five educational experts and survey of 72 in-service and pre-service teachers; aged from 19-62. Respondents were asked to explain the concept cultural understanding by their own words. They freely focused on ideas that comes to mind when thinking about cultural awareness. As all respondents are education practitioners; it can be assumed, that they also implement and evaluate the development of students' cultural understanding in this way.

\section{Results and Discussion}

The concepts cultural understanding, cultural awareness, cultural competence and cultural literacy are often used by contemporary educators as a matter of course, although each concept and each word has a wide range of meanings. Hereafter, the meanings of the words culture and understanding will be analysed.

The Oxford learner's dictionary offers three explanations of the word culture: 1) way of life, 2) art/ music/ literature and 3) beliefs/ attitudes (Oxford Learner's Dictionary, 2019). In other sources there two varieties are dominant: culture as an art and culture as a way of life, especially the general customs and believer of particular group of people (Cambridge Dictionary, 2019).

J. Fornäs emphasizes the opposition of the anthropological concept of culture and the "aesthetic" notion of culture as arts and artistic creativity. Culture in the aesthetic sense is usually implied by terms like cultural policy, cultural work or the cultural sector, and is often applied in institutional settings. It invites tensions between high and low taste, contrasting fine arts to popular culture and everyday aesthetics (Fornäs, 2017).

W. Griswold analyses four different meanings of culture: 1) high culture, as separated from everyday living and comprised of elevated activities and materials, such as fine and performing arts and literature; 2) culture as a coherent system, of norms, beliefs, values, and attitudes; organizing principle of society; 3) culture as a set of tools used by humans to make sense of their world; 4) culture as phenomenon, which affects social existence - oppressive, but at the same time - subject to change and transformation based on lived realities (Griswold, 2013).

Anthropologists argue that the concept of culture is very complex and ambiguous. Culture is explained in anthropology as learned and shared patterns of behaviour (Damen, 1987), symbolic, ideational and intangible aspects of human societies (Banks, McGee-Banks, 2015), collective programming of the human mind and others. In context of multicultural education, culture usually is defined as inherent to different social groups, encompassing race, ethnicity, nationality, language, religion, class, gender, sexual orientation (Farr, 2010). C. Geertz's understands the culture as "an accumulated totality of symbol-systems (religion, ideology, common sense, economics, sport, etc.) in terms of which people make sense of themselves and their world, and represent themselves to themselves and to others" (Geertz, 1977, 47). C. Geertz's "thick description" approach has become recognized as a method of symbolic anthropology, enlisted as a working antidote to overly technocratic, mechanistic means of understanding cultures, organizations, and historical settings. As P. Young summarizes: "Culture is everything! It is every-thing around us and everything ever created. Culture is all that is man-made, and even those things made by nature" (Young, 2014, 350).

It can be inferred, that the concept culture can be explained in two versions - as the arts and other manifestations of human intellectual achievement regarded collectively or the ideas, values, customs, social behaviour, life style of a particular person or society. Traditionally, the general education curriculum includes both of them either as particular school subjects - visual arts, music, literature, drama or as desired outcomes learning - civic responsibility, virtues, ethical attitudes.

The other opposition relates to the idea about student's understanding as a result of learning. It can be explained either in transmissive or transformative way. According with C.M. Halupa, in the case of transmissive learning, the highest level of learners' achievement is concluding, interpreting and estimating. In contrast, the transformative learning results as internalization and displaying one's knowledge (Halupa, 2017). Therefore, the rational and critical explanations of cultural phenomena are 
not enough for the student's cultural understanding; but the learner's subjective sense must be involved in study process, too. If the learning is personally meaningful, human's transformation can occur.

Theoretical sources dealing with the learner's personal transformation are approaches of experiential learning and in-depth learning. Experiential learning develops the idea about including the learner's personal and cultural experiences into educational process (Dewey, 2015; Jarvis, Holford, Griffin, 2003). In-depth cultural studies take for granted a holistic structure of culture: knowledge about the culture does not only refer to objective, evident facts, but also includes different layers of meanings, symbols, emotional experiences and complex contexts; they are open for ambiguous interpretations (Bennett, Grossberg, Morris, 2005; Grossberg, 2010; Hanley, 1999). The result of the deep learning is not only cognition, but a transformed person. On the contrary, surface learning deconstructs any structure, perceiving all phenomena of culture as equally significant, without constructing a system (Shusterman, 2002; Welsch, 1996). The learners understand the material correctly, but simply do not possess the connections between concepts (Draper, 2009).

It follows from R. Mason, that results of cultural learning are the recognition of and tolerance for the cultural diversity and the desire to preserve it as a valuable asset. Additionally, one can recognize a strong desire to preserve diversity in response to the threat of loss of cultural identity in the face of globalization and because of the benefits of community cohesiveness through unique cultural expression (Mason, 2007). In this respect, deep learning fits with socio-cultural learning theory which integrates learning as individual construction of knowledge in accordance with one's subjective sense and experience, with social learning and communicating cultural contexts (Helds, 2006). So, the deep learning can be recognized as productive way for cultural studies.

The various forms of the art education offer a wide range of information about cultural phenomena of different historical periods and countries. At the same time, reflection of one's aesthetical experiences are helpful for the noticing, acceptance and better understanding of one's own personal and cultural life and that of others. In art, transformative learning can be realized successfully through a holistic approach, as opposed to a technological (academic) one. Together with learning the means of artistic expression, this approach includes the development, reflection and analysis of personal self-expression and cultural contexts of art (Briška, 2012; Kalēja-Gasparoviča, 2012).

In EU key competences for life-long learning, the concept cultural awareness and expression is explained as increasing intercultural skills and the ability to express ideas in a variety of ways and contexts (European Commission, 2017). There, the culture is separated from language, civic, personal, social, learning and entrepreneurship competences. As the list of key competences is constructed in accordance with different fields of education, from it follows, that appropriate field for cultural education is art, but not the life, values, believes, way of life of the society on the whole. This principle is absolute in the Latvian basic education standard by declaring Cultural awareness and self-expression in art as a separate field of education, with its content - knowledge, understanding and basic skills in artistic expression. But the word culture appears there in language and social sciences, too: as related to identity, cultural heritage, multicultural understanding, tolerance and dignity, intercultural communication, culture of communication, cultural differences, events, cultural experiences. It does not occur in mathematics, science, technology, health and physical activity (Noteikumi par valsts..., 2018). From this follows that there is no consequent implementation of the concept cultural understanding in documents of education policy. The culture in aesthetic sense is separated there from the system of values, traditions and way of life of the society. So, this curriculum cannot be a proof basis for systemic development of general school students' deep cultural understanding.

It can be concluded, that the concept of cultural understanding in educational documents can be interpreted in different ways, even diametrically opposed:

1) the culture as related to art or to human life;

2) the learning as transmission or transformation.

These categories were indicated and interpreted in expressions or educational practitioners, too. Respondents' statements were read through several times, interpreted and coded according to the categories mentioned in the theory and education police documents - culture as art or culture as way of life, and transmissive or transformative learning approaches. 
Several statements related to more than one category. For example, the singing songs. If the respondent associates singing with a professional concert, it was interpreted as culture as art. If he recognizes to which culture the song belongs, it was related to culture as a life. Both variants are interpreted as representing the transmissive learning. However, if the respondent describes singing the song together with his family on a daily or festive basis, i.e. engagement and participation, "using" the culture, then it was categorized as a transformative approach. Some statements described the respondents' lack of understanding the question: "without explanation I can say nothing...." “... I can't really define it", "It seems that I need to start thinking terribly wise, now". Expression as "cultural diversity or People's Festival is only formal words" reveals respondent's critical attitude to the learning culture on superficial, formal level and can be interpreted as respondent's recognition of the transformative approach.

With all this in mind, the expressions were divided into four groups. Each group of expressions was revised again, looking for correlations, until it was possible to define 3-5 key words that accurately reflect the specific features of each type of cultural learning (Table 1).

Table 1

Appearance of 4 types of learning the culture in respondents' expressions.

\begin{tabular}{|c|c|c|}
\hline & Transmissive: Learning ABOUT & Transformative: Learning THROUGH \\
\hline $\begin{array}{l}1 . \\
\text { Culture } \\
\text { as art }\end{array}$ & $\begin{array}{l}\text { Fields of art } \\
\text { Paintings, theatre, books, music, dance. } \\
\text { Professional art education. } \\
\text { Various artistic expressions. } \\
\text { The expression of any art. } \\
\text { Art history } \\
\text { The National canon of culture. } \\
\text { Cultural symbols. } \\
\text { Cultural components, artistic and cultural } \\
\text { events. } \\
\text { Cultural heritage } \\
\text { Folk cultural heritage. } \\
\text { Folk songs and dances. }\end{array}$ & $\begin{array}{l}\text { Self-expression } \\
\text { Creation of art. } \\
\text { Painting, singing, dancing. } \\
\text { Aesthetic perception } \\
\text { People's view on different art forms } \\
\text { Perception of differences. } \\
\text { The pleasures of life. } \\
\text { Understanding the meaning of symbols and } \\
\text { cultural events. } \\
\text { Self-awareness } \\
\text { Individual believes, attitudes and principles of } \\
\text { thinking. } \\
\text { Spiritual diversity in the human soul. } \\
\text { Self-awareness and belonging to a specific time, } \\
\text { place, thinking mode, political situation. }\end{array}$ \\
\hline $\begin{array}{l}2 . \\
\text { Culture } \\
\text { as life }\end{array}$ & $\begin{array}{l}\text { Norms and values } \\
\text { Knowledge of cultural values. } \\
\text { We know that others have values, we value } \\
\text { them. } \\
\text { The norms of society, courtesy, etiquette. } \\
\text { Controlling the emotions. } \\
\text { Symbols } \\
\text { Events, traditions and symbols that make up } \\
\text { the culture of the country. } \\
\text { Understanding the cultural environment. } \\
\text { Cultural differences } \\
\text { My and other nationalities. } \\
\text { Know your own culture and that of other } \\
\text { nations. } \\
\text { Multiculturalism. } \\
\text { Current events in Latvia and the world. } \\
\text { Thoughts on culture and nations. } \\
\text { History } \\
\text { Past of your city and state. } \\
\text { Traditions } \\
\text { Festivities, events. } \\
\text { Family traditions and celebrations. } \\
\text { Aware of cultural traditions. } \\
\text { People's Day. }\end{array}$ & $\begin{array}{l}\text { Life } \\
\text { Culture is alive. } \\
\text { Culture is connected to the social environment; it } \\
\text { exists inside the life. } \\
\text { Culture is everything that happens around us. } \\
\text { Culture shapes an environment that connects } \\
\text { people and expands thinking. } \\
\text { Lifestyle. } \\
\text { Being cultural. } \\
\text { Participation } \\
\text { Family traditions and celebrations. } \\
\text { Traveling. } \\
\text { Behaving in society. } \\
\text { Providing support to those in need. } \\
\text { Identity } \\
\text { Belonging to your people. } \\
\text { Views on how Latvians see the world. } \\
\text { Independent living of one's own life. } \\
\text { Interaction } \\
\text { Ability to integrate into society. } \\
\text { Respect other people and the country we live in. } \\
\text { Mutual respect for difference. } \\
\text { Ability to accept cultural diversity. } \\
\text { Co-existence. }\end{array}$ \\
\hline
\end{tabular}

It is possible to see that on the left side 1, there are professional terms for art and on the right side 1 the description of individual feelings, abilities and experiences. On the left side 2 - social life and 
concepts of history, on the right side 2- attitudes, experience of values. It means, that implementation of particular categories are helpful for the recognizing particular pedagogical approach to the promoting of students' cultural understanding in school practice and educational documents.

\section{Model constructing}

There are two dimensions in the model of promoting the cultural understanding - content of learning and learning approach. The content of the learning can be focused either on art, by emphasizing the aesthetic sense of culture, or on all complexity of human life - anthropological understanding of culture. Learning approach variates from transmissive to transformative one: from learning about the culture to learning through it, from student's passive position to the active engagement, from learning the theory to self-realization, from knowledge acquisition to competent implementation of knowledge in life, from mechanical action to an organic and personally significant engagement into the world (Figure 1).

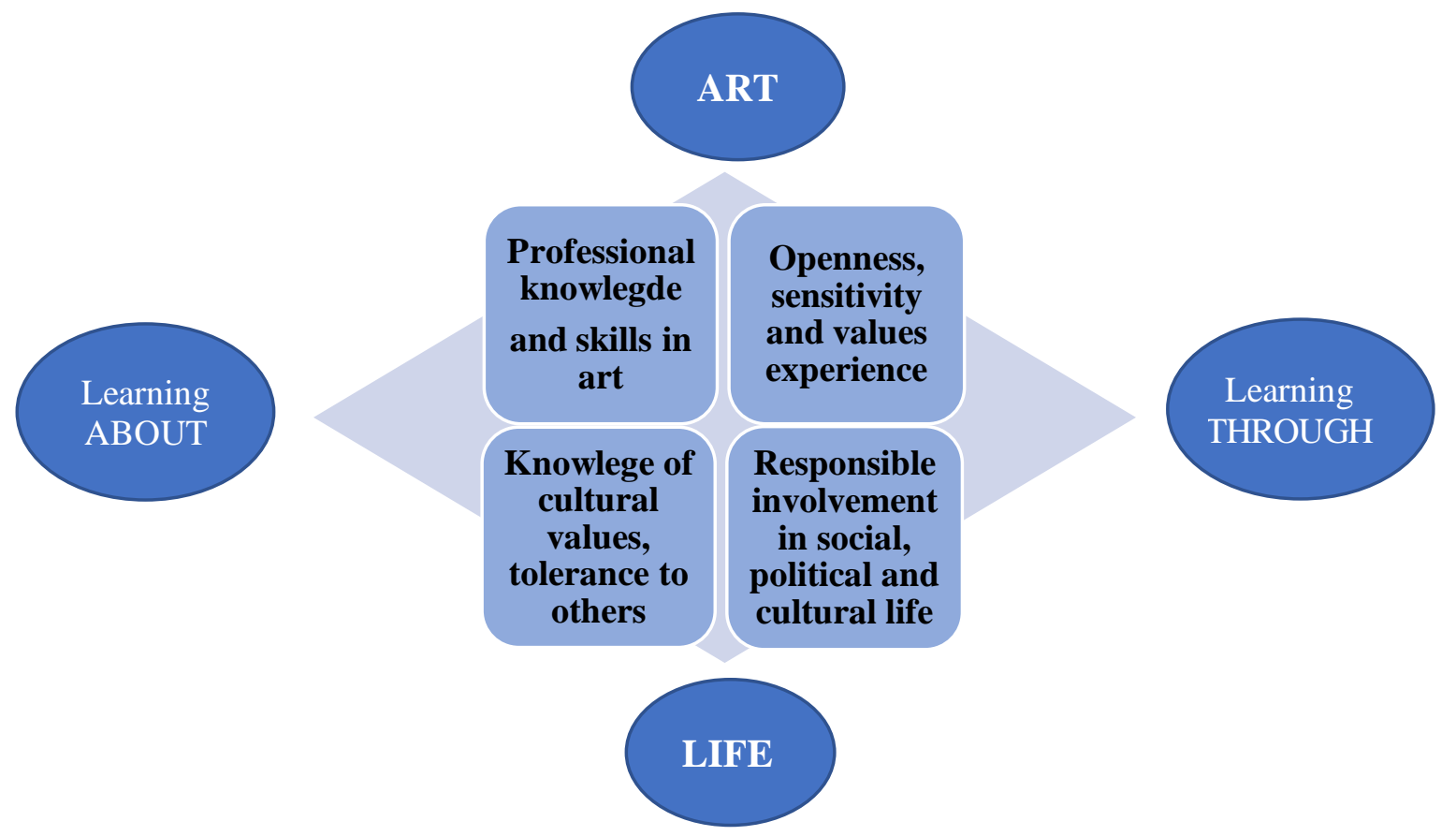

Figure 1. The model of learning culture in general school education.

These four components ( 2 - the content of learning and two - learning approaches) allow to construct 4 combinations, four types of the promoting cultural understanding, which are recognizable in general education. Each type proposes different aims and results, and different vocabulary, as well.

Type 1. The art as a content of learning is combined with a transmission approach to learning. Students learn about different artefacts, fields of professional and traditional art. They learn to produce the works of art of high technical quality. The context of the learning emerges as a history of art and a comparison of artworks from different countries and eras. Traditional folk song is perceived as a form of art that is performed on the stage. Phenomena outside the professional art are not interpreted as culture; cultural understanding does not relate to the life as a wholeness.

Type 2. In the art studies, the self-expression of an individual and the expression of cultural values in artwork are more important than technical skills. Students are supposed to learns through art. The art is not a goal, but a mean of transforming a learner's individuality and personality. The purposeful fostering of learner's self-expression and creativity in arts helps to make the artistic activities personally important. The focus on the aesthetic experiences in perceiving and producing the art helps to cultivate person's empathy not only to the artwork, but to other people and cultures, too (Briška, 2012; Kalēja-Gasparoviča, 2012).

Type 3. The content of learning the culture is closely related to the life, values and traditions of the particular country, religion, nation or other social group. The essential question for educator there is - is value learning deep or superficial, normative or meaningful one. If the result of learning the values is student's ability to name and distinguish them without personal experience of meaning, there will be no person's transformation. 
Student can learn "about" one's own and other cultures, he/ she can recognize the norms, for example, that one must behave with respect and dignity, but knowing what must be done is not the same as readiness to do and doing. Such learning can even meet the opposite goal - like an allergy to values in general.

Type 4. Educators are able to guarantee that the values, traditions, way of life as a content of learning the art or any other issue go together with a personal sense of meaning and involvement in activities that are important to society: student's cultural learning is transformative.

\section{Conclusions}

Consistent use of the concept cultural understanding can contribute for successful achievement of educational goals and for the mutual understanding of educators.

- Learning about art (transmissive approach) is useful, if the aim of the learning is professional excellence in particular field of art.

- If the aim of the learning is defined as understanding the cultural diversity (including one's own culture) and respect another culture, there is a risk that cultural understanding is superficial: without personal experience, the learning is transmissive, without the transformation of personality and society.

- If the aim of education is student's active participation in society and life processes, then learning must be deep, personally relevant, transformative.

- Learning through art helps to involve student's emotional experience, openness to new experience, tolerance towards unknown, unpredictable situations, creativity and aesthetic sensitivity, which are necessary for transforming the personality and society. Expression and reflection of the cultural values in art classes, promotes the development of student's attitudes towards the acceptance of the coexistence with other people and cultures.

- Educators and students need expanded vocabulary for nominating their experiences and describing the variety of cultural values.

The results of a study will help the all participants of general education (including teachers, politicians, teacher educators, researchers and school students) by clarifying the typical educational approaches and appropriate terminology for promoting the learners' cultural understanding.

\section{Bibliography}

1. Banks J.A., McGee-Banks C.A. (2015). Multicultural education: Issues and Perspectives ( $9^{\text {th }}$ ed.). UK: Wiley.

2. Bennett T., Grossberg M., Morris M. (Eds.). (2005). New Keywords: A Revised Vocabulary of Culture and Society. Malden, MA: Blackwell Pub. Retrieved from http://cscs.res.in/dataarchive/textfiles/textfile.2010-08-24.8343019985/file

3. Briška I. (2012). Fostering students' experience of holistic artistic creativity. The Scientific Articles of International conference "Person. Color. Nature. Music", Arts Lifelong Learning Program, 7, 103-115. Daugavpils: Daugavpils Universitātes akadēmiskais apgāds "Saule".

4. Cambridge Dictionary. (2019). Retrieved from https://dictionary.cambridge.org/dictionary/english/culture

5. Damen L. (1987). Culture learning: the fifth dimension in the language classroom. Cambridge: Cambridge University Press.

6. Dewey J. (2015). Democracy and Education: An Introduction to the Philosophy of Education. New York: The Free Press; London: Collier Macmillan.

7. Draper S.W. (2009). Catalytic assessment: Understanding how MCQs and EVS can foster deep learning. British Journal of Educational Technology, 40(2), 285-293. doi: 10.1111/j.14678535.2008.00920.x

8. European Commission. (2017). Developing key competences for all throughout life. Retrieved from https://ec.europa.eu/education/sites/education/files/document-library-docs/factsheet-keycompetences-lifelong-learning_en.pdf 
9. Farr S. (2010). Teaching As Leadership: The Highly Effective Teacher's Guide to Closing the Achievement Gap. San-Francisco: Jossey-Bass.

10. Fornäs J. (2017). The Aesthetic Concept of Culture as Art. Defending Culture. Palgrave Macmillan, Cham, 35-48. doi: 10.1007/978-3-319-57810-1_4

11. Geertz C. (1977). The Interpretation of Cultures. New York: Basic Books.

12. Griswold W. (2013). Cultures and societies of a changing world (4 ${ }^{\text {th }}$ ed.). Sage Publications Inc, London.

13. Grossberg L. (2010). Cultural Studies in the Future Tense. Durham, NC: Duke University Press.

14. Halupa C.M. (2017). Transformative curriculum design. In Medical Education and Ethics: Concepts, Methodologies, Tools, and Applications, 439-487. Hershey, PA: IGI Global. doi: 10.4018/978-1-5225-0978-3.ch021

15. Hanley J.H. (1999). Beyond the tip of the iceberg. Five stages toward cultural competence. Reaching today's youth, 3(2), 9-12.

16. Helds J. (2006). Mācīšanās kā konstruktīvs un sistēmisks jēdziens [Learning as constructive and systemic concept]. In I. Maslo (Ed.), Rakstu krājums No zināšanām uz kompetentu darbību. Rīga: LU akadēmiskais apgāds, 31-35. (in Latvian).

17. Jarvis P., Holford J., Griffin C. (Eds.). (2003). The theory and practice of learning. London and New York: Routledge Falmer.

18. Kalēja-Gasparoviča D. (2012). The students creative experience enrichment in visual art studies. In V. Dislere (Ed.), The Proceedings of the International Scientific Conference Rural Environment. Education. Personality. (REEP), 5. Jelgava: LLU, 223-230. Retrieved from https://llufb.llu.lv/conference/REEP/2012/REEP-2012-proceedings-E-ISSN-2255-808X.pdf

19. Mason R. (2007). Internationalizing education. In M.G. Moore (Ed.), Handbook of distance education ( $2^{\text {nd }}$ ed.), 583-591. Mahwah, NJ: Lawrence Erlbaum Associates.

20. Noteikumi par valsts pamatizglìtības standartu un pamatizglìtības programmu paraugiem [Regulations on the National Standard for Basic Education and Models of Basic Education Programs]. (2018). Ministru kabineta noteikumi Nr.747. Retrieved from https://likumi.lv/ta/id/303768 (in Latvian)

21. Oxford Learner's dictionaries. (2019). Retrieved from https://www.oxfordlearnersdictionaries.com/definition/american_english/culture_1

22. Shusterman R. (2002). Surface and Depth. Dialectic of Criticism and Culture. Cornell University Press.

23. Young P. (2014). The presence of culture in learning. In J. Spector, M. Merrill, J. Elen, M. Bishop (Eds.), Handbook of educational communication and technology. New York, NY: Springer doi: 10.1007/978-1-4614-3185-5_28

24. Welsch W. (1996). Grenzgänge der Ästhetik [Limits of aesthetics]. Stuttgart: Reclam (in German) 